\title{
THE MOVING SPLIT WINDOW (MSW) ANALYSIS IN VEGETATION SCIENCE - AN OVERVIEW
}

\author{
ERDÖS, L.* - BÁTORI, Z. - TÖLGYESI, CS. - KÖRMÖCZI, L. \\ ${ }^{1}$ University of Szeged, Department of Ecology \\ 6726 Szeged, Közép fasor 52. \\ (phone: +36-62-546-951; fax: +36-62-546-949) \\ *Corresponding author \\ e-mail: Erdos.Laszlo@bio.u-szeged.hu \\ (Received $13^{\text {th }}$ May 2014 ; accepted $22^{\text {nd }}$ July 2014)
}

\begin{abstract}
Boundaries are key entities in understanding ecological patterns and mechanisms. If challenges of fragmentation and global changes are to be met, objective techniques are needed to describe boundary characteristics and predict future dynamics. In vegetation science, the moving split window (MSW) technique has been efficiently used for boundary analysis. However, a wider but more rigorous application of the method could considerably promote our understanding of vegetation pattern and organization. First, we briefly describe the MSW method and its history. Next, we review publications that used MSW for field data to analyse vegetation boundaries. We also evaluate the studies that investigated MSW properties. Since such studies are scarce, our own additional tests are also provided. The MSW has been used in a multitude of different environments to answer highly diverse study questions. Study layouts (e.g. transect length, plot size, window width) have been plentiful. As for future directions, the MSW could broaden our knowledge on vegetation continuity vs. discontinuity and abioticbiotic relations. It should more widely be used to study boundary dynamics. Real cross-scale studies could be achieved by using considerably different window widths without averaging the resulting dissimilarities. A significance test is needed for the correct interpretation of the results.
\end{abstract}

Keywords: boundary, ecotone, transect, dissimilarity profile, dissimilarity indices

\section{Introduction}

In vegetation science, knowledge on boundaries (i.e. locations that separate adjacent biotic zones) is essential in understanding basic ecological patterns and processes on several scales (Holland, 1988; Cadenasso et al., 2003; Ries et al., 2004). Boundaries may be defined as positions where the rate of change in the measured properties is the highest (Fortin and Drapeau, 1995; Fortin et al., 2000). Boundaries play an important role in landscape ecology, community ecology and nature conservation (Yarrow and Marín, 2007). Given the intensive habitat fragmentation and boundary alterations due to global changes, a profound ecological knowledge on boundaries is crucial, if the natural values of landscapes are to be maintained and correctly managed (Hansen et al., 1988; di Castri and Hansen, 1992; Risser, 1995; Laurance et al., 2001).

The most important boundary characteristics include spatial position, boundary width, sharpness, geometric shape and dynamics (cf. Strayer et al., 2003). To study these features, objective methods are needed. For this purpose, several techniques have been used during the past few decades (Kent et al., 1997; Jacquez et al., 2000; Fortin and Dale, 2005; Hufkens et al., 2009). For boundary analysis, the most commonly used methods include ordination (e.g. Werger et al., 1983; Carter et al., 1994; Erdős et al., 2008), wavelet analysis (e.g. Bradshaw and Spies, 1992; Dale and Mah, 1998; Camarero et al., 2006) and wombling (e.g. Fortin, 1994; Fortin and Drapeau, 1995; 
Fortin et al., 2000). Beside them, the moving split window technique is probably the most popular.

The moving split window technique (MSW) detects boundaries along onedimensional (transect) data (cf. Kent et al., 1997). Its popularity is due to the fact that it is relatively simple, robust and powerful (Ludwig and Cornelius, 1987; Johnston et al., 1992). Consequently, the number of studies using the MSW is relatively high. However, we think there is a considerable potential in this method that has not been exploited yet. In this article we provide a brief description of the MSW method and a summary of how MSW emerged as a valuable tool in ecology. Next, we review 40 published studies that used the MSW for field data. In addition, we evaluate the studies that used simulated data for the analysis of the behaviour of the MSW under known circumstances. Since studies focusing on MSW-properties are scarce, a few of our own tests are also summarized in the present article. We provide some suggestions on the appropriate MSW layouts, on the significance tests and randomization procedures, and identify the main directions where MSW holds great promise.

\section{The MSW technique: a brief description}

For MSW studies, a field transect has to be established, consisting of a series of contiguous or non-contiguous plots. The transect is usually gradient-oriented, that is, it is placed perpendicular to the presumed boundary/boundaries (this study design is also called gradsect; Gillison and Brewer, 1985) (Fig. 1a). Variables such as species presence/absence data or cover values are registered within each plot. Then, at one end of the transect, a window is assigned, which is split into two half-windows. In the simplest case, a half-window consists of one plot. The two half-windows are compared, using a dissimilarity function. The window is then shifted along the transect by one plot in each step, and the function is computed in all positions. The procedure is repeated until the end of the transect. If the dissimilarity function is plotted against spatial position, boundaries appear as peaks (Fig. 1b). Half-window size can be increased, thus the analysis can be done on several spatial scales (Webster, 1978; Brunt and Conley, 1990; Fortin and Dale, 2005; Körmöczi, 2005). High and narrow peaks indicate sharp boundaries, whereas low and wide peaks form where boundaries are blurred (Ludwig and Cornelius, 1987). Double peaks that merge at larger window widths indicate transitional zones positioned between the two peaks. In contrast, double peaks that do not merge at increasing window widths indicate distinct patches that are situated in a homogeneous matrix (Körmöczi, 2005 Erdős et al., 2014).

\section{A short history of the MSW technique}

The first analysis similar to what is known today as moving split window analysis, was carried out by Whittaker (1960). However, there were two differences compared to the MSW. Firstly, similarities were calculated instead of dissimilarities; secondly, and more importantly, similarity profiles were drawn in a topological space (that is, the order of plots in the profile did not reflect their order in the real space). In subsequent studies, dissimilarity profiles were prepared in a topographical space. Beals (1969) used the approach to reveal potential discontinuities along altitudinal vegetation gradients in Ethiopia. Van der Maarel $(1974,1976)$ also suggested that vegetation boundaries may be delineated effectively by drawing differential profiles. This method is essentially

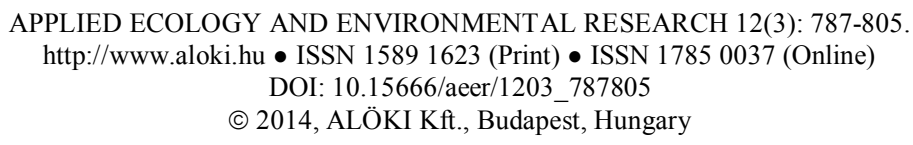


identical to the moving split window analysis, although the possibility of increasing the window width was not considered yet.

The MSW method in the strict sense was used first in soil science (Webster and Wong, 1969; Webster, 1973, 1978; Nwadialo and Hole, 1988). Since the late 1980s, MSW has been applied increasingly in vegetation science (some early examples include Wierenga et al., 1987; Cornelius et al., 1991; Ludwig and Tongway, 1995) and later in animal ecology as well (Ross et al., 2001; Magura, 2002; Gallé et al., 2007; Torma and Körmöczi, 2009). Moreover, MSW was used to analyse satellite images (e.g. Chang et al., 2003), in which case the plots are the pixels of the image, and they are compared based on their reflectance. Also, there have been important contributions testing the properties of the MSW, using both real and simulated data (Brunt and Conley, 1990; Choesin and Boerner, 2002; Körmöczi, 2005; Erdös et al., 2013, 2014).

(a)

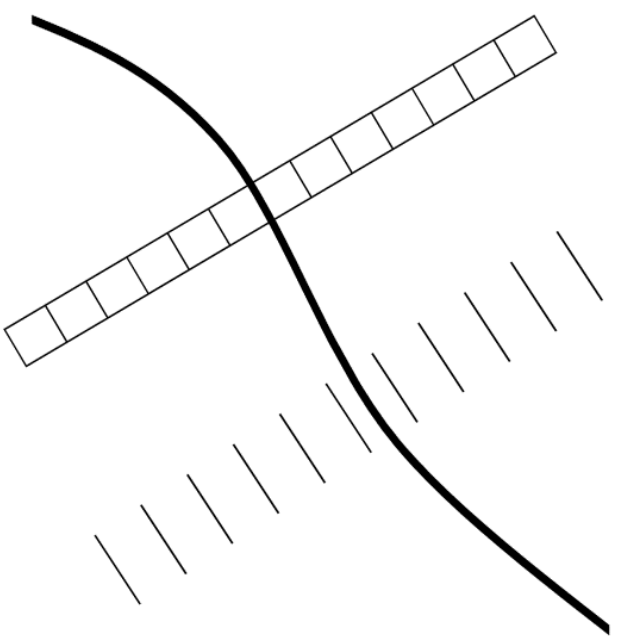

(b)
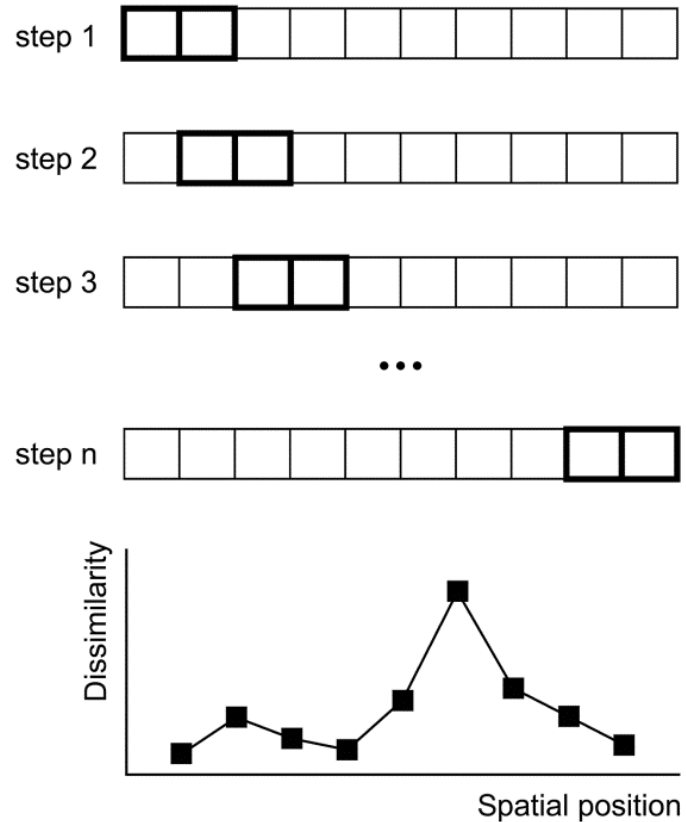

Figure 1. Transect analysis in MSW. (a) Gradient-oriented transects (gradsects) of contiguous quadrates (up) and lines (down) across a presumed boundary. (b) Schematic representation of the MSW analysis and the resulting dissimilarity profile (based on Fortin and Dale, 2005)

\section{The use of the MSW in vegetation science}

In vegetation science, moving split window analysis has been used in several environments (Table 1) of every continent except Antarctica. The majority of these studies were carried out in arid or semi-arid regions (xeric grasslands, shrublands and deserts). The method can successfully be used to analyse boundaries between woody and herbaceous vegetation (e.g. forest-grassland), as well as to study boundaries between different types of forests (e.g. coniferous-deciduous) and those between grasslands (e.g. open-closed). 
Table 1. Habitats under scrutiny and the main study focus of 40 vegetation studies using $M S W$. 'b' means boundary

\begin{tabular}{|c|c|c|}
\hline Author(s) & Habitat & Main study focus \\
\hline 1 Azevedo and Caçador 1999 & holm-oak forest & Boundary location \\
\hline 2 Bátori et al. 2014 & mesic forests & Distinctness of doline bottoms \\
\hline 3 Beals 1969 & semiarid shrublands & Continuity or discontinuity? \\
\hline 4 Boughton et al. 2006 & shrubland & $\begin{array}{l}\text { Boundary location } \\
\text { Boundary dynamics (sharpness - fires) } \\
\text { Elevation - communities }\end{array}$ \\
\hline 5 Camarero et al. 2006 & $\begin{array}{l}\text { alpine treeline } \\
\text { (Pinus uncinata) }\end{array}$ & $\begin{array}{l}\text { Boundary location } \\
\text { Canopy boundary - plant richness boundary }\end{array}$ \\
\hline 6 Chang et al. 2003 & $\begin{array}{l}\text { mountain birch forest/ } \\
\text { coniferous forest }\end{array}$ & Boundary location and width \\
\hline 7 Choesin 2001 & alkaline wetland & Visual boundaries - MSW-boundaries \\
\hline 8 Choesin and Boerner 2002 & alkaline wetland & Visual boundaries - MSW-boundaries \\
\hline 9 Dupuch and Fortin 2013 & boreal forest edge & Depth of edge influence \\
\hline 10 Erdős et al. 2011 & shrubforest/rock sward & $\begin{array}{l}\text { Boundary location and width } \\
\text { Edge diversity }\end{array}$ \\
\hline 11 Erdős et al. 2012 & $\begin{array}{l}\text { mesic and xeric forests } \\
\text { and grasslands }\end{array}$ & $\begin{array}{l}\text { Boundary sharpness } \\
\text { Boundary densities on different slopes }\end{array}$ \\
\hline 12 Erdős et al. 2013 & $\begin{array}{l}\text { mesic and xeric forests } \\
\text { and grasslands }\end{array}$ & $\begin{array}{l}\text { Boundary location at multiple scales } \\
\text { Landscape hierarchy }\end{array}$ \\
\hline 13 Harper and Macdonald 2001 & $\begin{array}{l}\text { boreal forest edge } \\
\text { (selected plant species) }\end{array}$ & Boundary location \\
\hline 14 Hennenberg et al. 2005 & tropical forest/savanna & $\begin{array}{l}\text { Boundaries of different vegetation layers } \\
\text { Depth of edge influence }\end{array}$ \\
\hline $15 \mathrm{lbanez}$ et al. 2013 & rainforest/savanna & Boundary dynamics \\
\hline 16 Kirkman et al. 1998 & wetland/upland & $\begin{array}{l}\text { Boundary location } \\
\text { Vegetation boundaries - soil boundaries }\end{array}$ \\
\hline 17 Körmöczi and Jusztin 2003 & sandy grassland & $\begin{array}{l}\text { Boundary location and sharpness } \\
\text { Boundary dynamics }\end{array}$ \\
\hline 18 Kröger et al. 2009 & wetland/upland & $\begin{array}{l}\text { Boundary location } \\
\text { Vegetation b. - topographic b. - soil b. } \\
\text { Boundaries in } 2 \text { dimensions }\end{array}$ \\
\hline 19 Kröger and Rogers 2005 & wetland/upland & $\begin{array}{l}\text { Boundary location } \\
\text { Grazing animals' habitat preference }\end{array}$ \\
\hline 20 Laliberte et al. 2007 & wetland/upland & Boundary location \\
\hline 21 Li et al. 2005 & $\begin{array}{l}\text { coniferous forest/cultivated } \\
\text { land, broadleaved } \\
\text { forest/grassland }\end{array}$ & Depth of edge influence \\
\hline 22 Li et al. 2007 & $\begin{array}{l}\text { coniferous forest/cultivated } \\
\text { land, broadleaved } \\
\text { forest/cultivated land }\end{array}$ & $\begin{array}{l}\text { Depth of edge influence } \\
\text { Soil properties edge influence - vegetation } \\
\text { edge influence }\end{array}$ \\
\hline 23 Ludwig and Tongway 1995 & semiarid forest/grassland & $\begin{array}{l}\text { Boundary location at multiple scales } \\
\text { Landscape hierarchy }\end{array}$ \\
\hline 24 Muños-Reinoso 2001 & Mediterranean shrubland & $\begin{array}{l}\text { Boundary location } \\
\text { Geomorphology - vegetation boundaries }\end{array}$ \\
\hline 25 Muños-Reinoso and García Novo 2000 & Mediterranean shrubland & $\begin{array}{l}\text { Boundary location } \\
\text { Geomorphology - soil - vegetation b. }\end{array}$ \\
\hline 26 Muños-Reinoso and García Novo 2005 & Mediterranean shrubland & $\begin{array}{l}\text { Boundary location } \\
\text { Geomorphology - soil - vegetation b. }\end{array}$ \\
\hline 27 Muños-Reinoso 2009 & Mediterranean shrubland & $\begin{array}{l}\text { Boundary location } \\
\text { Landscape hierarchy }\end{array}$ \\
\hline 28 Nishimura and Kohyama 2002 & subalpine coniferous forests & $\begin{array}{l}\text { Boundary location } \\
\text { Topography - soil depth - vegetation b. }\end{array}$ \\
\hline 29 Pärn et al. 2010 & wetland/upland & $\begin{array}{l}\text { Boundary location } \\
\text { Soil b. - topographic b. - vegetation b. }\end{array}$ \\
\hline 30 Ross et al. 2001 & wetland/upland & $\begin{array}{l}\text { Boundary location } \\
\text { Vegetation b. - algae b. - invertebrate b. - } \\
\text { physical b. }\end{array}$ \\
\hline 31 Stanisci et al. 2000 & mountain beech timberline & $\begin{array}{l}\text { Timberline structure } \\
\text { Boundary dynamics }\end{array}$ \\
\hline 32 Tolman 2006 & savanna/fen & Vegetation boundaries - soil boundaries \\
\hline 33 Torma and Körmöczi 2009 & sandy grassland & $\begin{array}{l}\text { Boundary location } \\
\text { Vegetation b. - true bug community } b .\end{array}$ \\
\hline 34 Watkins et al. 2003 & hardwood forest & Depth of edge influence \\
\hline 35 Wierenga et al. 1987 & desert & $\begin{array}{l}\text { Boundary location } \\
\text { Vegetation boundaries - soil boundaries }\end{array}$ \\
\hline 36 Cornelius et al. 1991 & desert & $\begin{array}{l}\text { Boundary location } \\
\text { Vegetation boundaries - abiotic boundaries }\end{array}$ \\
\hline $37 \mathrm{Xu}$ et al. 2012 & $\begin{array}{l}\text { arid-semiarid sandy land/ } \\
\text { steppe }\end{array}$ & $\begin{array}{l}\text { Boundary location } \\
\text { Vegetation boundaries - soil boundaries }\end{array}$ \\
\hline 38 Zalatnai and Körmöczi 2004 & alkaline grassland & $\begin{array}{l}\text { Visual boundaries - MSW-boundaries } \\
\text { Boundary sharpness } \\
\text { Vegetation boundaries - microtopography }\end{array}$ \\
\hline 39 Zalatnai et al. 2007 & alkaline grassland & $\begin{array}{l}\text { Visual boundaries - MSW-boundaries } \\
\text { Vegetation boundaries - soil boundaries } \\
\text { Boundary sharpness - abiotic stress }\end{array}$ \\
\hline 40 Zalatnai et al. 2008 & alkaline grassland & $\begin{array}{l}\text { Visual boundaries - MSW-boundaries } \\
\text { Vegetation boundaries - soil boundaries } \\
\text { Boundary sharpness }\end{array}$ \\
\hline
\end{tabular}

APPLIED ECOLOGY AND ENVIRONMENTAL RESEARCH 12(3): 787-805. http://www.aloki.hu • ISSN 15891623 (Print) • ISSN 17850037 (Online)

DOI: $10.15666 /$ aeer/1203 787805

(c) 2014, ALÖKI Kft., Budapest, Hungary 
Study questions that can be answered by the MSW method are highly diverse (Table 1). In most cases, the exact and objective identification of boundary location is the primary and most important purpose. After the delineation of the boundaries, transect segments are usually further analysed. This may provide useful information for nature conservation (e.g. Kröger and Rogers, 2005; Erdős et al., 2011; Bátori et al., 2014).

The correspondence between visually delineated boundaries and boundaries identified by the MSW can also be studied (e.g. Choesin and Boerner, 2002; Zalatnai and Körmöczi, 2004). According to Zalatnai et al. (2007), the greater the environmental stress (in that case, salinity), the stricter the coincidence.

Another exciting question is whether or not different types of ecological boundaries coincide. Numerous studies have analysed how boundaries in abiotic parameters (such as soil factors and topography) influence vegetation boundaries. In some cases, the two boundary types are in the same position (e.g. Wierenga et al., 1987; Kröger et al., 2009), while in other cases, they are not (e.g. Zalatnai et al., 2007; Pärn et al., 2010; Xu et al., 2012). Similarly, the boundaries of different vegetation components or vegetation layers may be compared (e.g. Hennenberg et al., 2005; Camarero et al., 2006). The study of the correspondence between vegetation boundaries and animal community boundaries is also possible (Ross et al., 2001; Torma and Körmöczi, 2009).

The MSW method can also be used to determine boundary width or depth of edge influence, as was done by Watkins et al. (2003) in a temperate hardwood forest, by Hennenberg et al. (2005) in tropical forest patches and by Dupuch and Fortin (2013) in old-growth boreal forests.

Based on the MSW technique, detailed studies on vegetation dynamics are also possible, using either direct (long-term researches) or indirect (space for time substitution) methods. The results of Stanisci et al. (2000) indicate that Italian beech timberlines with shrubby mantle may move upwards, while those without a mantle are stable. Körmöczi and Jusztin (2003) identified stable, shifting and directionally moving boundaries in a sandy grassland. The study of Boughton et al. (2006), conducted in a Florida shrubland, suggests that fire makes boundaries sharper, but as time passes after the fire event, boundaries become more diffuse. From sharp and blurred boundaries, Ibanez et al. (2013) inferred that stable and unstable phases alternate in rainforestsavanna boundary dynamics. Interestingly, Dupuch and Fortin (2013) found that in uncut forests adjacent to logged areas, the depth of edge influence increased as the logged areas regenerated.

MSW may help to put boundaries in a broader context (i.e. the role of community boundaries in the landscape can be studied). The analysis of Muñoz-Reinoso (2001) showed that boundaries appear in a regular pattern, appr. $1500 \mathrm{~m}$ away from one another in a Spanish shrubland. In a comparison of differently exposed slopes, Erdős et al. (2012) found that the density of boundaries is higher on south-facing mountain slopes than on north-facing ones, probably due to different soil properties and microclimate.

Since MSW operates on several spatial scales, it allows the study of hierarchical organization of the vegetation. Boundaries of at least two different organizational levels have been detected in an Australian vegetation mosaic by Ludwig and Tongway (1995). Using large window widths, the MSW identified boundaries between alternating tree groves and treeless intergroves. Smaller window widths revealed a pattern of a lower level, where the undergrowths of the individual trees, shrubs and log mounds were separated by open areas. Boundaries of three nested hierarchical levels were 
demonstrated in the Mediterranean shrublands of Spain (Muñoz-Reinoso, 2009). On a regional level, a boundary separates the coastal shrubland zone from the inland grasslands and marshes. On an intermediate level, boundaries separate vegetation types of different aged dune series. The lowest hierarchical level deals with neighbouring shrub communities on the dune slopes. In a Hungarian mountain region, Erdős et al. (2013) used strongly different window widths and identified a boundary type between two community-complexes on a coarse scale, as well as the community boundaries within each complex on a finer scale.

Height and width of the peaks in an MSW profile indicate the abruptness of the spatial changes along the transect, thus the method provides an excellent opportunity to characterize boundary sharpness. Regular sampling (transect) along a gradient and the objective boundary delineation of the MSW may significantly contribute to the theories associated with a basic ecological controversy, namely the community-unit vs. continuum debate. Comparing the plant communities of steep and gentle slopes, Beals (1969) concluded that in some cases, vegetation discontinuity develops even when the environmental gradient is continuous, which is similar to the Clementsian view of plant communities. However, under different conditions, the vegetational change is more or less continuous, which is close to the Gleasonian concept. Other studies have confirmed that in nature, both sharp and blurred boundaries occur, and in some cases changes are so gradual, that no boundaries can be identified (Kirkman et al., 1998; Erdös et al., 2012). It is a related topic where and how gradual changes in abiotic parameters result in sharp boundaries in vegetation. For example, Zalatnai et al. (2008) found that in alkaline grasslands, vegetation boundaries are usually sharp and narrow, while soil boundaries are wider and more gradual.

A major drawback of the MSW is that it is confined to one dimension. However, from a study design of several parallel transects, two-dimensional information can be gained, as shown by Kröger et al. (2009). This may be less reliable than the methods specifically designed for two-dimensional spatial analyses (e.g. wombling). Nevertheless, it can provide reasonably useful results, yet it is less labour-intensive and less destructive.

\section{MSW layouts: transect length, sampling units, window width and dissimilarity indices}

In literature, transect lengths vary between $9 \mathrm{~m}$ and $300 \mathrm{~km}$, but about half of the studies apply transects of 50-500 m (Table 2), which are usually appropriate for identifying the boundaries between vegetation units on the landscape scale. As for the sampling units, quadrates are by far the most popular, but the line intercept approach is also efficient. Circular plots (Ross et al., 2001) and point quadrates (Camarero et al., 2006) have also been used in some studies. The necessary resolution clearly depends on the purpose of the study and the structure of the vegetation under scrutiny: in the case of quadrates, sampling unit sizes range from $100 \mathrm{~cm}^{2}$ to $250 \mathrm{~m}^{2}$. For most studies, quadrate size of 1-25 $\mathrm{m}^{2}$ has proved to be appropriate. Quadrates are most often contiguous, but in the case of very long transects, this is not possible or not needed. However, it should be kept in mind that too large distances between non-contiguous plots risk that some spatial phenomena remain undetected, especially if the vegetation is patchy (Fig. 2). The distance between adjacent sampling plots is almost always constant along the 
whole transect. The two exceptions we found were the studies of Beals (1969) and that of Watkins et al. (2003).

Table 2. MSW layouts in 40 vegetation studies. Sampling unit type: $C$ : circular plot, LI: line intercept, P: point quadrat, Q: quadrat. Basic sampling unit size: A: canopy, B: shrub layer, $C$ : herb layer; S: seedlings and saplings. $M S W$ window width: ' $a$ ' means that the results were averaged over several window widths, numbers in parenthesis indicate window widths tested in pilot studies but not further evaluated. MSW index: BC: Bray-Curtis index, CB: city block, $C D$ : coefficient of dissimilarity, $C H$ : chord distance, $D$ : difference of species cover, DREN: complement of the Renkonen-similarity index, ED: Euclidean distance, SCB: squared city block, SED: squared Euclidean distance, SMD: squared Mahalanobis distance

\begin{tabular}{|c|c|c|c|c|c|c|}
\hline Author(s) & $\begin{array}{c}\text { Transect } \\
\text { lenght }\end{array}$ & $\begin{array}{c}\text { Sampling unit } \\
\text { type }\end{array}$ & $\begin{array}{c}\text { Basic } \\
\text { sampling unit } \\
\text { size }\end{array}$ & $\begin{array}{l}\text { Distance of } \\
\text { sampling } \\
\text { units }\end{array}$ & $\begin{array}{c}\text { MSW } \\
\text { window width }\end{array}$ & $\begin{array}{l}\text { MSW } \\
\text { index }\end{array}$ \\
\hline 1 Azevedo and Caçador 1999 & $25 \mathrm{~m}$ & $\mathrm{LI}$ & $10 \mathrm{~m}$ & $5 \mathrm{~m}$ & 2 & SED \\
\hline 2 Bátori et al. 2014 & $10-243 \mathrm{~m}$ & $Q$ & $1 \mathrm{~m} \times 1 \mathrm{~m}$ & - & $2-30$ & DREN \\
\hline 3 Beals 1969 & $20-300 \mathrm{~km}$ & Q & $10 \mathrm{~m} \times 20 \mathrm{~m}$ & inconstant & 10 & $\mathrm{CD}$ \\
\hline 4 Boughton et al. 2006 & $30-147 \mathrm{~m}$ & $\mathrm{LI}$ & $1 \mathrm{~m}$ & - & $12,16,20$ a $(2-20)$ & SCB \\
\hline 5 Camarero et al. 2006 & $100-140 \mathrm{~m}$ & $\mathrm{P}$ & $\mathrm{d}=2 \mathrm{~mm}$ & $1 \mathrm{~m}$ & $10(2-20)$ & $\mathrm{D}$ \\
\hline 6 Chang et al. 2003 & $510 \mathrm{~m}$ & $\mathrm{Q}$ & $1 \mathrm{~m} \times 2 \mathrm{~m}$ & - & $2-30$ & SED \\
\hline 7 Choesin 2001 & $72-134 \mathrm{~m}$ & $Q$ & $1 \mathrm{~m} \times 0.5 \mathrm{~m}$ & - & 8 & SED \\
\hline 8 Choesin and Boerner 2002 & $49-134 m$ & $\hat{Q}$ & $1 \mathrm{~m} \times 0.5 \mathrm{~m}$ & - & $8(2,4,8,16)$ & SED \\
\hline 9 Dupuch and Fortin 2013 & $300 \mathrm{~m}$ & $Q$ & $\begin{array}{c}2 \mathrm{~m} \times 2 \mathrm{~m} \mathrm{AS} \\
1 \mathrm{~m} \times 1 \mathrm{~m} \mathrm{C}\end{array}$ & $10 \mathrm{~m}$ & $7-15$ & SMD \\
\hline 10 Erdős et al. 2011 & $20-40 \mathrm{~m}$ & $Q$ & $1 \mathrm{~m} \times 1 \mathrm{~m}$ & - & $2-20 a$ & SED \\
\hline 11 Erdős et al. 2012 & $200 \mathrm{~m}$ & $Q$ & $1 \mathrm{~m} \times 1 \mathrm{~m}$ & - & $2-20 a$ & SED \\
\hline 12 Erdős et al. 2013 & $382 \mathrm{~m}$ & $\vec{Q}$ & $1 \mathrm{~m} \times 1 \mathrm{~m}$ & - & $\begin{array}{l}10-20 \text { a, } 30-40 a \\
50-60 a, 70-80 a\end{array}$ & SED \\
\hline 13 Harper and Macdonald 2001 & $200 \mathrm{~m}$ & $\mathrm{Q}$ & $10 \mathrm{~cm} \times 10 \mathrm{~cm}$ & - & $\begin{array}{c}40,200(20,40, \\
80,120,160,200)\end{array}$ & CB \\
\hline 14 Hennenberg et al. 2005 & $260-305 \mathrm{~m}$ & $Q$ & $\begin{array}{c}5 \mathrm{~m} \times 10 \mathrm{~m} \mathrm{ABC} \\
5 \mathrm{~m} \times 30 \mathrm{~m} \mathrm{AB} \\
5 \mathrm{~m} \times 50 \mathrm{~m} \mathrm{~A}\end{array}$ & - & $2-20 a$ & ED \\
\hline 15 Ibanez et al. 2013 & $120 \mathrm{~m}$ & $Q$ & $1 \mathrm{~m} \times 20 \mathrm{~m}$ & - & $10,20,30,40 a$ & ED \\
\hline 16 Kirkman et al. 1998 & $87 \mathrm{~m}$ & $Q$ & $1 \mathrm{~m} \times 3 \mathrm{~m}$ & $3 \mathrm{~m}$ & 4 & SED \\
\hline 17 Körmöczi and Jusztin 2003 & $55 \mathrm{~m}$ & Q & $25 \mathrm{~cm} \times 25 \mathrm{~cm}$ & - & $2-40 a$ & $\begin{array}{l}\text { SED, } \\
\text { DREN }\end{array}$ \\
\hline 18 Kröger et al. 2009 & ca. $150 \mathrm{~m}$ & $Q$ & $\begin{array}{c}0.5 \mathrm{~m} \times 0.5 \mathrm{~m}, \\
1 \mathrm{~m} \times 1 \mathrm{~m}\end{array}$ & - & $2-10$ & SED \\
\hline 19 Kröger and Rogers 2005 & ca. $150 \mathrm{~m}$ & $Q$ & $0.5 \mathrm{~m} \times 0.5 \mathrm{~m}$ & - & $?$ & SED \\
\hline 20 Laliberte et al. 2007 & $30 \mathrm{~m}$ & $\mathrm{Q}$ & $1 \mathrm{~m} \times 1 \mathrm{~m}$ & $1 \mathrm{~m}$ & $2-4$ & SED \\
\hline $21 \mathrm{Li}$ et al. 2005 & $50 \mathrm{~m}$ & $\mathrm{Q}$ & $2 \mathrm{~m} \times 5 \mathrm{~m}$ & - & $6-10(2-14)$ & SED \\
\hline 22 Li et al. 2007 & $50 \mathrm{~m}$ & $Q$ & $2 \mathrm{~m} \times 5 \mathrm{~m}$ & - & 6,8 & SED \\
\hline 23 Ludwig and Tongway 1995 & $300 \mathrm{~m}, 500 \mathrm{~m}$ & $Q$ & $1 \mathrm{~m} \times 1 \mathrm{~m}$ & - & 10,100 & ED \\
\hline 24 Muños-Reinoso 2001 & $10.5 \mathrm{~km}$ & $\mathrm{LI}$ & $30 \mathrm{~m}$ & $100 \mathrm{~m}$ & 4 & $\mathrm{CH}$ \\
\hline 25 Muños-Reinoso and García Novo 2000 & $10.5 \mathrm{~km}$ & $\mathrm{LI}$ & $30 \mathrm{~m}$ & $100 \mathrm{~m}$ & $4-12 a$ & $\mathrm{CH}$ \\
\hline 26 Muños-Reinoso and García Novo 2005 & $10.5 \mathrm{~km}$ & $\mathrm{LI}$ & $30 \mathrm{~m}$ & $100 \mathrm{~m}$ & $4-12 a$ & $\mathrm{CH}$ \\
\hline 27 Muños-Reinoso 2009 & $110 \mathrm{~m}$ & $Q$ & $5 \mathrm{~m} \times 5 \mathrm{~m}$ & - & 4 & ED \\
\hline 28 Nishimura and Kohyama 2002 & $50 \mathrm{~m}$ & $\mathrm{LI}$ & $?$ & - & $10 \mathrm{~m}$ & SED \\
\hline 29 Pärn et al. 2010 & $125-195 \mathrm{~m}$ & $Q$ & $1 \mathrm{~m} \times 20 \mathrm{~m}$ & - & 4 & ED \\
\hline 30 Ross et al. 2001 & $3.9 \mathrm{~km}$ & $\mathrm{C}$ & $\mathrm{d}=10 \mathrm{~m}$ & $100 \mathrm{~m}$ & 4 & $\mathrm{BC}$ \\
\hline 31 Stanisci et al. 2000 & $14-38 \mathrm{~m}$ & $Q$ & $1 \mathrm{~m} \times 1 \mathrm{~m}$ & - & $6(4-8)$ & SED \\
\hline 32 Tolman 2006 & $9-24 m$ & $\bar{Q}$ & $\begin{array}{l}1 \mathrm{~m} \times 1 \mathrm{~m}, \\
5 \mathrm{~m} \times 5 \mathrm{~m}\end{array}$ & - & 4 & SED \\
\hline 33 Torma and Körmöczi 2009 & $55 \mathrm{~m}$ & $\bar{Q}$ & $25 \mathrm{~cm} \times 25 \mathrm{~cm}$ & - & $2-40 a$ & $\begin{array}{l}\text { SED, } \\
\text { DREN }\end{array}$ \\
\hline 34 Watkins et al. 2003 & $150 \mathrm{~m}$ & $Q$ & $1 \mathrm{~m} \times 1 \mathrm{~m}$ & $5 \mathrm{~m}-30 \mathrm{~m}$ & 2 & SED \\
\hline 35 Wierenga et al. 1987 & $2.7 \mathrm{~km}$ & $\mathrm{LI}$ & $30 \mathrm{~m}$ & $30 \mathrm{~m}$ & $8(4-12)$ & SED \\
\hline 36 Cornelius et al. 1991 & $2.7 \mathrm{~km}$ & $\mathrm{LI}$ & $30 \mathrm{~m}$ & $30 \mathrm{~m}$ & 6 & SED \\
\hline 37 Xu et al. 2012 & $110 \mathrm{~km}$ & $Q$ & $\begin{array}{c}1 \mathrm{~m} \times 1 \mathrm{~m} \mathrm{C} \\
2 \mathrm{~m} \times 2 \mathrm{~m} \mathrm{C} \\
10 \mathrm{~m} \times 10 \mathrm{~m} \mathrm{~B} \\
5 \mathrm{~m} \times 20 \mathrm{~m} \mathrm{~B}\end{array}$ & $2 \mathrm{~km}$ & $8(2-12,16)$ & SED \\
\hline 38 Zalatnai and Körmöczi 2004 & $17 \mathrm{~m}, 19 \mathrm{~m}$ & $\mathrm{Q}$ & $10 \mathrm{~cm} \times 10 \mathrm{~cm}$ & - & 4-60 partly a & DREN \\
\hline 39 Zalatnai et al. 2007 & $15 \mathrm{~m}$ & Q & $10 \mathrm{~cm} \times 10 \mathrm{~cm}$ & - & $2-40 a$ & $\begin{array}{l}\text { SED, } \\
\text { DREN }\end{array}$ \\
\hline 40 Zalatnai et al. 2008 & $30 \mathrm{~m}$ & $\mathrm{Q}$ & $10 \mathrm{~cm} \times 20 \mathrm{~cm}$ & - & $2-40 a$ & $\begin{array}{l}\text { SED, } \\
\text { DREN }\end{array}$ \\
\hline
\end{tabular}


(a)

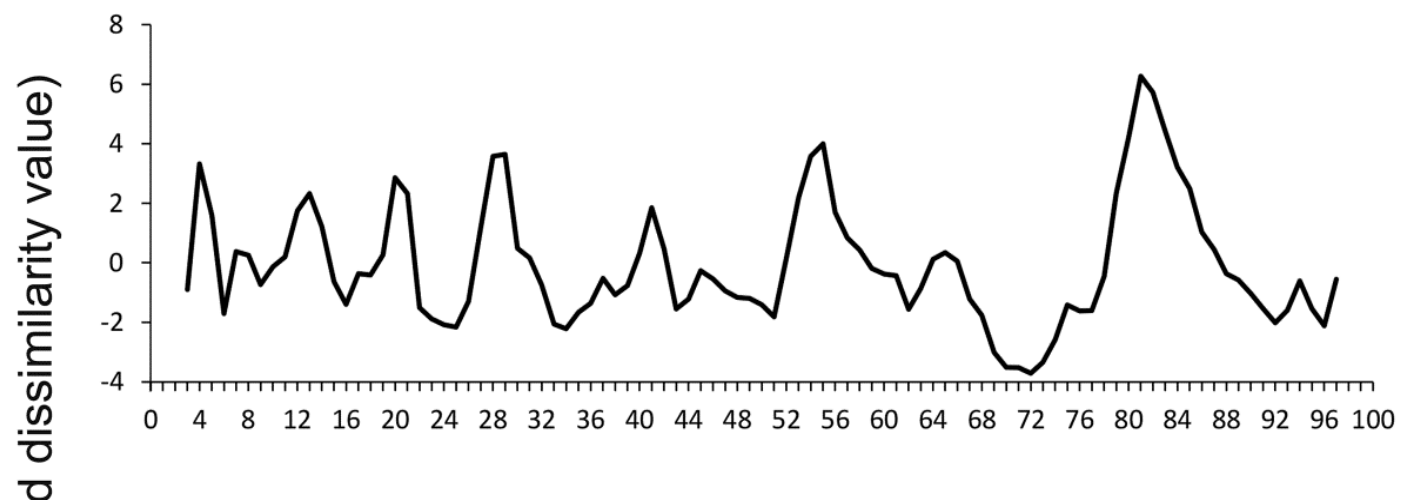

(b)

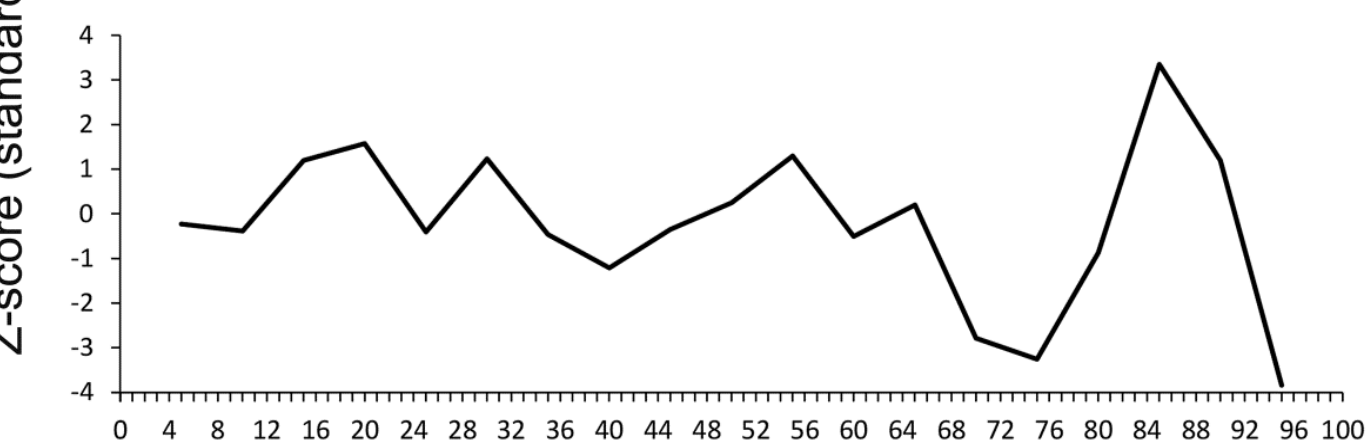

Spatial position (m)

Figure 2. If vegetation is patchy, some spatial information may be lost when applying noncontiguous quadrates. More peaks appear in the case of (a) contiguous quadrates than in the case of (b) non-contiguous ones, where a distance of $4 \mathrm{~m}$ was set between neighbouring plots. In both cases, $z$-scores were averaged over window widths that were equal to $6 \mathrm{~m}-16 \mathrm{~m}$. Note the different scale of the vertical axes. Data originate from a $100 \mathrm{~m}$ long transect in a xeric grassland-forest mosaic

In the 40 studies we reviewed, a total of ten different comparative indices were used (Table 2), with the Squared Euclidean Distance (SED) as the most common among them. The SED index is favoured because it is quite sensitive and usually results in high peaks, although it does have some undesirable characteristics as well. Firstly, it is scaledependent (this property can be reduced by averaging standardized values over several window sizes). Secondly, it is very sensitive to differences in species abundaces, overemphasizing even minor differences, but cannot distinguish between abundance differences and compositional differences (Brunt and Conley, 1990; Körmöczi, 2005).

The window widths used in different studies vary considerably (Table 2), since the choice depends on the focus of the study and on the data resolution (Choesin and Boerner, 2002). Generally, too small window widths often make results hard to interpret due to high sample-to-sample noise (Brunt and Conley, 1990; Choesin and Boerner 2002). This phenomenon is a result of internal inhomogeneity of the vegetation patches (Whittaker, 1960; Zalatnai and Körmöczi, 2004). On the other hand, it is assumed that valuable information may be lost when using too wide windows, because this can 
homogenize small patches (Choesin and Boerner, 2002; Kröger et al., 2009). Based on his experience with soil transects, Webster (1978) suggested that, in a patchy environment, window widths equal to two third of the assumed patch sizes should be used. In practice, usually various window widths are tested before the seemingly best width is chosen for final data analysis (e.g. Nishimura and Kohyama, 2002; Camarero et al., 2006; Xu et al., 2012). To reduce scale-dependence of the analysis, it is advisable to average the results from several window widths (e.g. Muñoz-Reinoso and García Novo, 2000, 2005; Boughton et al., 2006) because peaks in the resulting MSW profile are less scale-dependent than peaks from individual window widths.

Concerning window widths, the overwhelming majority of the studies using MSW fall into one of the following three categories (Table 2). 17 of the 40 reviewed articles $(42.5 \%)$ opted for a single window width that was considered "not too small" and "not too large". Four studies (10\%) used a few very similar window widths. Finally, 12 researches $(30 \%)$ were carried out using strongly different window widths, but the results were averaged (i.e. dissimilarity values from all window widths were averaged). Beside their advantages, all of the above procedures have a serious drawback: they cannot differentiate between coarse-scale and fine-scale boundaries. As Ludwig and Tongway (1995) pointed out, the detection of boundaries at different spatial scales requires the use of different window widths without averaging them. Wide windows identify coarse-scale boundaries, while small windows detect fine-scale boundaries. Erdös et al. (2013) drew the same conclusion from simulated and field data. In sum, if the complex pattern of a landscape is to be revealed, including both coarse-scale and fine-scale boundaries, small and large windows should also be used in the MSW analyses.

\section{Significance tests}

The most challenging issue concerning the MSW method is the significance test of the peaks (Körmöczi, 2005). Of the studies under review, 45\% did not use any test to determine which peaks in the profile can be considered significant (Table 3), whereas another $7.5 \%$ used an arbitrary confidence limit.

The simplest way of selecting significant peaks is to assume normal distribution of dissimilarity. In this case, peaks over the value of $P$ probability should be considered significant. Randomizations provide an opportunity to test whether a detected peak differs significantly from those appearing in a random pattern (Fagan et al., 2003). Some authors apply random reference to compute the expected mean and standard deviation (SD), and consider peaks significant if they exceed mean plus one (MuñozReinoso and García Novo, 2000, 2005; Muñoz-Reinoso, 2001; Laliberte et al., 2007) or two standard deviations (Cornelius and Reynolds, 1991; Körmöczi and Jusztin, 2003; Zalatnai and Körmöczi, 2004; Körmöczi, 2005). Expected mean value, however, depends on the window width and the type of randomization (Cornelius and Reynolds, 1991; Körmöczi, 2005). Therefore, $z$-score transformation is often used to make the dissimilarity profile less scale dependent (Cornelius and Reynolds, 1991). Z-score transformation is a normalizing transformation, and calculated as follows:

$$
z_{k}=\frac{d_{i, k}-d_{\exp , k}}{S D_{\exp , k}}
$$


where $z_{k}$ is the standardized dissimilarity value, $d_{i, k}$ is the dissimilarity value at position $i$ if the half-window size is $k, d_{\text {exp, } k}$ is the overall mean of the dissimilarity value from randomized data for half-window size $k$ (expected mean), and $S D_{\text {exp, } k}$ is the standard deviation of the dissimilarity values from the randomized data for half-window size $k$. The probabilities of standard normal distribution may be applicable as confidence limits (Hennenberg et al., 2005; Boughton et al., 2006; Zalatnai et al., 2007, 2008; Erdős et al., 2011).

Overall mean dissimilarity and standard deviation vary with transect length and boundary numbers. This has profound influences on the statistical significance of the boundaries. It has been demonstrated that the shorter the transect is and the more boundaries are along it, the higher the chance that the MSW peaks will not be significant (Körmöczi, 2005).

In a recent study, we compared the distribution of the expected dissimilarities with normal distribution (Erdős et al., 2012). Unlike Cornelius and Reynolds (1991), we found significant deviation from the normal distribution: the observed distribution was skewed to the right, and the confidence limits proved to be higher than for the normal distribution. Therefore, $z=1.85$ was applied as critical value for $P=0.05$, instead of $z=1.65$. Pärn et al. (2010) also mention the deviation of the distribution of Euclidean distances from normal distribution, without any further consideration or analysis.

\section{Randomization procedure}

As mentioned above, the type of the randomization is also a crucial point of the analysis since it provides the null model. Expected mean dissimilarity and standard deviation can be calculated from random reference. Randomization of data can be carried out in several different ways (Table 3). Usually, Monte Carlo procedure is applied in the form of either completely mixing the abundance values of the species (Fig. 3a), or with random relocation of plots (Fig. 3b) (Cornelius and Reynolds, 1991; Hennenberg et al., 2005). However, Palmer and van der Maarel (1995) and Fortin et al. (1996) suggested the random shift method, during which the species distributions are randomly shifted relative to one another (Fig. 3c). According to Fagan et al. (2003), complete randomization should be avoided. In fact, both random relocation of plots and random shift have a sound ecological meaning: plot relocation preserves within-plot cooccurrences of species, while random shift preserves spatial pattern of species distributions (cf. Horváth, 1998).

In a comparison of the above three randomizations, we found that z-scores remain more stable with increasing window widths in the case of random shift than in the case of the other two randomizations (Fig. 4). The phenomenon appeared in several different habitat types as well as in analyses of simulated patterns. This should be considered a potential advantage of random shift, since it may ease interpretation of the $\mathrm{z}$-score profile when strongly different window widths have to be used.

As for the number of randomizations, usually 1000 iterations are applied (Table 3). This number is high enough, since the expected mean and standard deviation are stabilized over 100 randomizations, as reported by Körmöczi (2005). 
Table 3. Significance tests and randomization procedures applied in 40 vegetation studies using the MSW. Question marks appear where details were not given in the cited article

\begin{tabular}{|c|c|c|c|c|}
\hline Author(s) & Significance test & Distribution considered & $\begin{array}{c}\text { Randomization } \\
\text { type }\end{array}$ & $\begin{array}{l}\text { Number of } \\
\text { randomizations }\end{array}$ \\
\hline 1 Azevedo and Caçador 1999 & - & - & - & - \\
\hline 2 Bátori et al. 2014 & $z>1.85$ & random reference & plot $r$. & 1000 \\
\hline 3 Beals 1969 & - & - & - & - \\
\hline 4 Boughton et al. 2006 & $z>1.65$ & normal distribution & plot $r$. & 1000 \\
\hline 5 Camarero et al. 2006 & $\mathrm{D}>90 \%$ & - & - & - \\
\hline 6 Chang et al. 2003 & - & - & - & - \\
\hline 7 Choesin 2001 & SED>3500 & - & - & - \\
\hline 8 Choesin and Boerner 2002 & SED $>3500$ & - & - & - \\
\hline 9 Dupuch and Fortin 2013 & - & - & - & - \\
\hline 10 Erdős et al. 2011 & $z>1.65$ & normal distribution & r. shift & 99 \\
\hline 11 Erdős et al. 2012 & $z>1.85$ & random reference & r. shift & 99 \\
\hline 12 Erdős et al. 2013 & $z>1.85$ & random reference & r. shift & 99 \\
\hline 13 Harper and Macdonald 2001 & - & - & - & - \\
\hline 14 Hennenberg et al. 2005 & $z>1.65$ & normal distribution & plot $r$. & 1000 \\
\hline 15 Ibanez et al. 2013 & $z>1.65$ & normal distribution & $?$ & $?$ \\
\hline 16 Kirkman et al. 1998 & - & - & - & - \\
\hline 17 Körmöczi and Jusztin 2003 & $\begin{array}{l}\text { SED>mean+2SD, } \\
\text { DREN>mean+2SD }\end{array}$ & normal distribution & r. shift & 1000 \\
\hline 18 Kröger et al. 2009 & - & - & - & - \\
\hline 19 Kröger and Rogers 2005 & - & - & - & - \\
\hline 20 Laliberte et al. 2007 & SED>mean+SD & no consideration & - & - \\
\hline 21 Li et al. 2005 & - & - & - & - \\
\hline 22 Li et al. 2007 & - & - & - & - \\
\hline 23 Ludwig and Tongway 1995 & - & - & - & - \\
\hline 24 Muños-Reinoso 2001 & $\mathrm{z}>$ mean+SD & no consideration & $?$ & $?$ \\
\hline 25 Muños-Reinoso and García Novo 2000 & $\begin{array}{c}z>\text { mean+SD } \\
+ \text { MRPP }\end{array}$ & no consideration & plot $r$. & $?$ \\
\hline 26 Muños-Reinoso and García Novo 2005 & $\begin{array}{c}z>\text { mean+SD } \\
+ \text { MRPP }\end{array}$ & no consideration & plot $\mathrm{r}$. & $?$ \\
\hline 27 Muños-Reinoso 2009 & MRPP & distribution free & $?$ & $?$ \\
\hline 28 Nishimura and Kohyama 2002 & - & - & - & - \\
\hline 29 Pärn et al. 2010 & $\begin{array}{l}\text { one tailed, } 95 \% \\
\text { limit }\end{array}$ & random reference & plot r. & 1000 \\
\hline 30 Ross et al. 2001 & - & - & - & - \\
\hline 31 Stanisci et al. 2000 & - & - & - & - \\
\hline 32 Tolman 2006 & - & - & - & - \\
\hline 33 Torma and Körmöczi 2009 & $z>1.65$ & normal distribution & r. shift & 1000 \\
\hline 34 Watkins et al. 2003 & SED>mean+2SD & normal distribution & - & - \\
\hline 35 Wierenga et al. 1987 & - & - & - & - \\
\hline 36 Cornelius et al. 1991 & - & - & - & - \\
\hline 37 Xu et al. 2012 & - & - & - & - \\
\hline 38 Zalatnai and Körmöczi 2004 & DREN>mean+2SD & normal distribution & complete & 1000 \\
\hline 39 Zalatnai et al. 2007 & $z>1.65$ & normal distribution & r. shift & 1000 \\
\hline 40 Zalatnai et al. 2008 & $z>1.65$ & normal distribution & r. shift & 1000 \\
\hline
\end{tabular}

\section{Softwares for MSW-computations}

The computation of dissimilarity metrics in the MSW analysis is not a big challenge, it can be performed even with a spreadsheet software (e.g. Choesin, 2001). This works well with a single window width, but dealing with multiple window widths and handling randomized data are rather difficult in such a way. The PASSaGE software also contains the computation of a dissimilarity profile (Rosenberg and Anderson, 2011). This software package is declared as "a free, integrated, easy-to-use software package for performing spatial analysis and statistics on biological and other data" (http://www.passagesoftware.net/). Unfortunately, it is also limited to a single window size, and is without random reference. Computations can be done in the $\mathrm{R}$ environment. 
For example, the software of Rossiter (http://www.itc.nl/personal/rossiter/teach/R/R_OptPart.pdf) enables to carry out MSWanalyses using multiple window widths and it offers two dissimilarity indices. However, it does not offer any randomizations.

We used in this paper and in earlier works our own software that was developed in the statistical language $\mathrm{R}$ (version 2.10.1, www.R-project.org). The source code was published in Erdős et al. (2014).

(a)

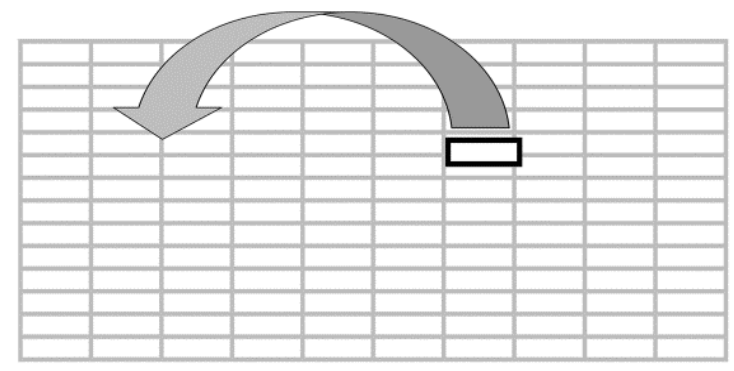

(b)

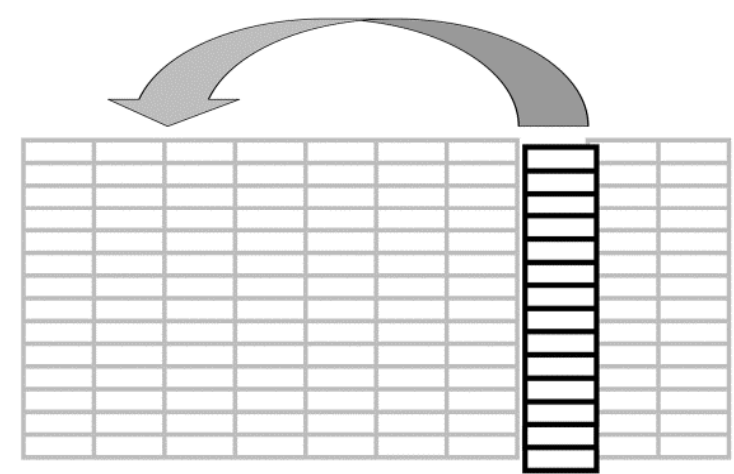

(c)

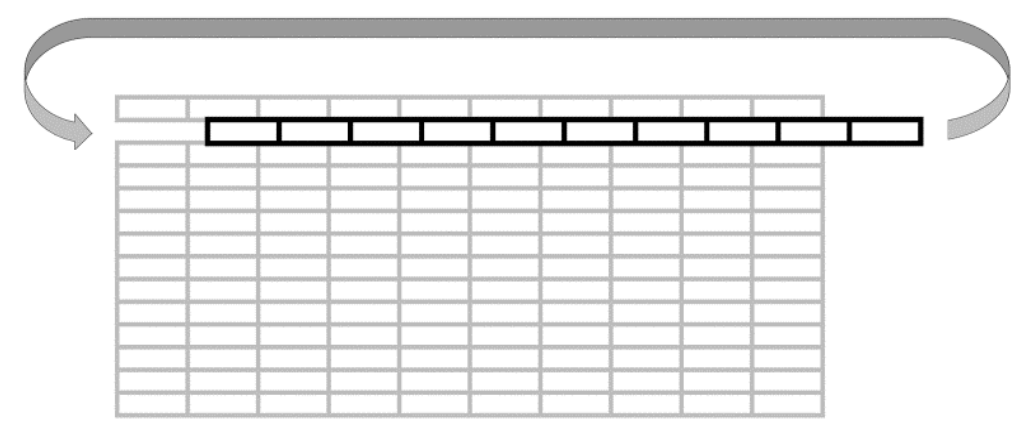

Figure 3. Three possible randomization types, applied in earlier MSW studies. Each row corresponds to a species and each column to a relevé. (a) In the case of complete randomization, data are randomly relocated within their own row. (b) Plot randomization relocates each relevé into a new position along the transect. (c) During random shift, data belonging to the same species are shifted along the transect. Values shifted beyond the end of the transect are wrapped back on to the opposite end 


\section{Conclusions and future directions}

An ever increasing literature on the moving split window clearly indicates the method's usefulness in vegetation science. We conclude that it is a reliable technique for the analysis of boundaries, and may prove effective in any habitat type.

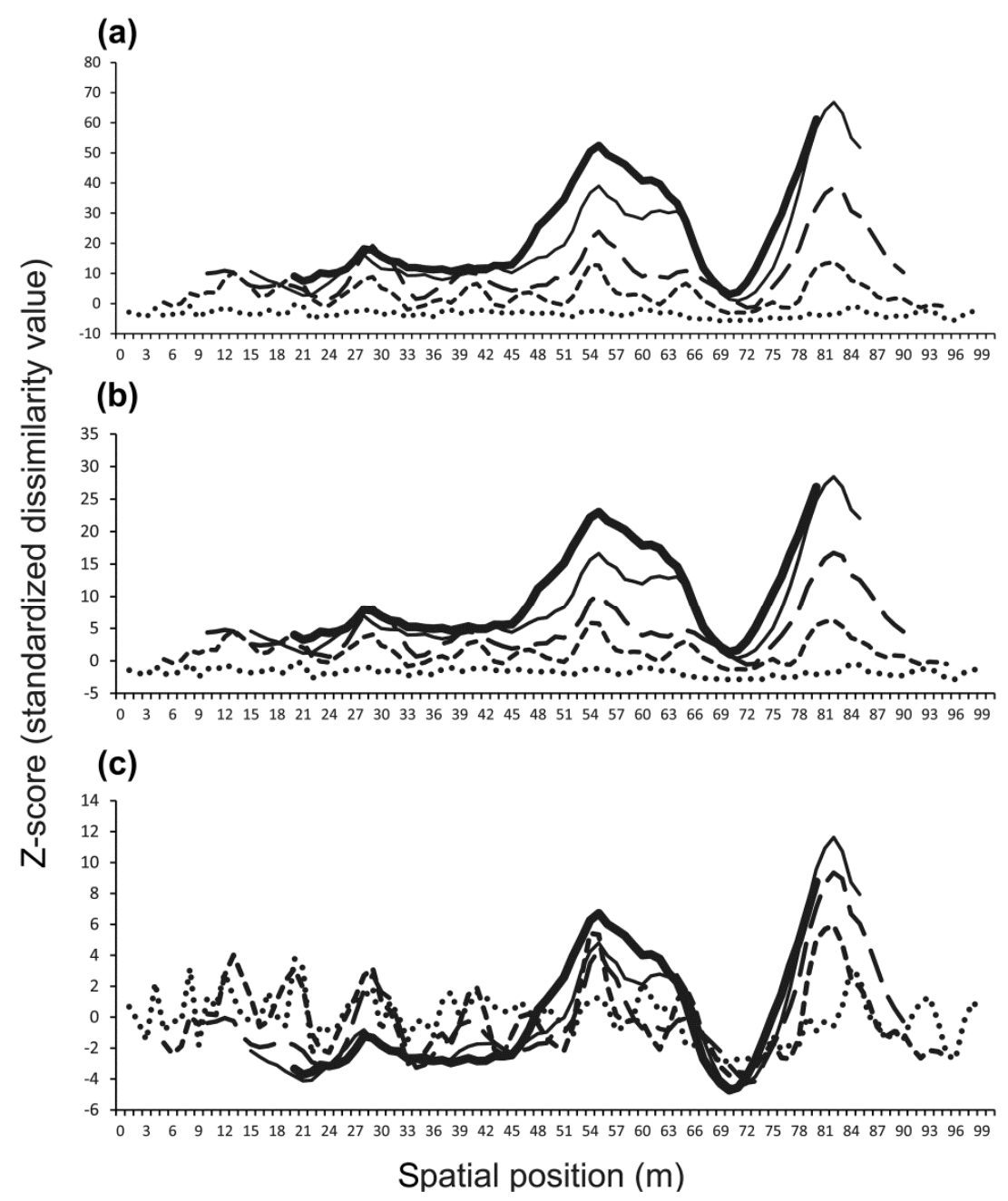

Figure 4. Dependence of z-scores on window width. If window width is changed, z-scores vary considerably in the case of (a) complete randomization and (b) plot randomization, but there is small variability if (c) random shift is used. Note the different scale of the vertical axes. Data originate from a $100 \mathrm{~m}$ long transect in a xeric grassland-forest mosaic. Different lines indicate different window widths

As we see it, a wider application of the MSW, accompanied by appropriate setting of the parameters (mainly window width) and correct statistical tests would result in a deeper understanding of the vegetation pattern and organization. We identified four areas where the MSW method holds promise for future research.

Firstly, MSW has the potential to provide objective and accurate information for some of the basic controversies in vegetation science: it can broaden our knowledge on vegetation continuity vs. discontinuity as well as on abiotic-biotic relations, issues connected to the Clements-Gleason debate. Although there have been important 
contributions in these topics, we think that a more wide-spread use of the MSW, followed by correct interpretation would support further development. It is generally accepted that in nature, both sharp and blurred boundaries occur, and continuous transitions (without boundaries) are also possible (e.g. Hobbs, 1986; Cadenasso et al., 2003; Fagan et al., 2003), and this observation has been verified by MSW analyses as well (e.g. Beals, 1969; Kirkman et al., 1998; Ibanez et al., 2013). However, it should be emphasized that this does not say much about the Clements-Gleason controversy, since Clements' and Gleason's perspectives are often misinterpreted. For example, Gleason (1926) did not deny the existence of sharp boundaries between plant communities. To have a more correct understanding of the original concepts, abiotic-biotic relations should be taken into consideration. According to Clements (1936), relatively sharp vegetation boundaries form even if the gradient of the background factors is continuous. In contrast, Gleason (1926) predicts that sharp vegetation boundaries appear only where there are abrupt changes in background factors (for a more complete view on this topic, see Daubenmire, 1966; Whittaker, 1967; Ricklefs, 1973; Begon et al., 1990; Collins et al., 1993; Callaway, 1997; Hoagland and Collins, 1997; Kent et al., 1997; Wilson, 2004, 2009; Austin, 2005). Through rigorous analyses of biotic and abiotic gradients, MSW may contribute to the knowledge on this topic.

Secondly, it is presumed that boundaries react sensitively to local, regional and global changes (Gosz and Sharpe, 1989; Fortin et al., 2000). Therefore, long-term monitoring projects are necessary to track alterations in boundary position and structure. Using the MSW method, it can be studied whether boundaries can change position or remain stable, whether their sharpness changes or not, whether they can disappear or new boundaries appear where they were not present earlier. Unfortunately, to the best of our knowledge, only five studies used MSW to answer similar questions. Four of them (Stanisci et al., 2000; Boughton et al., 2006; Dupuch and Fortin, 2013; Ibanez et al., 2013) used indirect methods (i.e. they inferred temporal dynamics from spatial information). The fifth one (Körmöczi and Jusztin, 2003) provided a real temporal analysis, but only for four years.

Thirdly, cross-scale studies are among the most challenging and promising directions in the ecology of boundaries (Gosz, 1993; Laurance et al., 2001). With the help of MSW, it is possible to analyse boundaries on different spatial scales and on different hierarchical levels at the same time. This can be used for a better understanding of the hierarchical organization of landscapes and vegetation. However, this capacity has rarely been used so far. If boundaries of different scales are to be distinguished, strongly different window widths have to be used, without averaging the results. This would enable a multi-level vegetation study, as was carried out by Ludwig and Tongway (1995) and Erdős et al. (2013, 2014).

Finally, Kröger et al. (2009) have shown that MSW may help reveal two dimensional vegetation pattern. In our opinion, if the huge data requirements of the wombling method cannot be supplied, the approach of Kröger et al. (2009) should be used, provided the somewhat uncertain results are handled carefully.

As for the MSW layouts, we suggest that contiguous quadrates be used whenever possible. Although several dissimilarity indices have been used, we think that SED is probably the best among them. Also, since the majority of the former studies used SED, using SED in any future studies will make their results easier to compare to the former ones. Since distance functions are insensitive to the common information that the 
neighbouring plots share, functions other than distance functions (e.g. complement of the Renkonen index) may also be used in additional analyses.

Carrying out a significance test is strongly advisable for the correct interpretation of the results. On the basis of a great number of analyses we found that z-transformed peaks over 1.85 should be accepted as significant at $P<0.05$. Exploration of the distribution and the scale-dependence of significance values is in progress, and will be reported later.

When comparing the three different randomization procedures, results were found similar, though random shift can be considered the best choice for two reasons, namely because $z$-scores are less scale-dependent with random shift, than with the other two randomizations (Fig. 4), and because the random shift method preserves the population patterns, which should be regarded as a desirable property.

Acknowledgements. We are thankful to the Inspectorate for Environment, Nature and Water and to the Directorate of the Kiskunság National Park for allowing us to collect field data in some strictly protected nature reserves.

\section{REFERENCES}

[1] Austin, M.P. (2005): Vegetation and environment: discontinuities and continuities. - In: van der Maarel, E. (ed.) Vegetation ecology, Blackwell, Oxford.

[2] Azevedo, J., Caçador, F. (1999): Bordaduras de bosques de Quercus rotundifolia Lam. no Parque Natural de Montesinho. - Quercetea 1: 163-176.

[3] Bátori, Z., Csiky, J., Farkas, T., Vojtkó, E.A., Erdős, L., Kovács, D., Wirth, T., Körmöczi, L., Vojtkó, A. (2014): The conservation value of karst dolines for vascular plants in woodland habitats of Hungary: refugia and climate change. - Internatinal Journal of Speleology 43: 15-26.

[4] Beals, E.W. (1969): Vegetational change along altitudinal gradients. - Science 165: 981985.

[5] Begon, M., Harper, J.L., Townsend, C.R. (1990): Ecology: individuals, populations and communities, 2nd edn. - Blackwell, Cambridge.

[6] Boughton, E.A., Quintana-Ascencio, P.F., Menges, E.S., Boughton, R.K. (2006): Association of ecotones with relative elevation and fire in an upland Florida landscape. Journal of Vegetation Science 17: 361-368.

[7] Bradshaw, G.A., Spies, T.A. (1992): Characterizing canopy gap structure in forests using wavelet analysis. - Journal of Ecology 80: 205-215.

[8] Brunt, J.W., Conley, W. (1990): Behavior of a multivariate algorithm for ecological edge detection. - Ecological Modelling 49: 179-203.

[9] Cadenasso, M.L., Pickett, S.T.A., Weathers, K.C., Bell, S.S., Benning, T.L., Carreiro, M.M., Dawson, T.E. (2003): An interdisciplinary and synthetic approach to ecological boundaries. - BioScience 53: 717-722.

[10] Callaway, R.M. (1997): Positive interactions in plant communities and the individualistic-continuum concept. - Oecologia 112: 143-149.

[11] Camarero, J.J., Gutiérrez, E., Fortin, M-J. (2006): Spatial patterns of plant richness across treeline ecotones in the Pyrenees reveal different locations for richness and tree cover boundaries. - Global Ecology and Biogeography 15: 182-191.

[12] Carter, V., Gammon, P.T., Garrett, M.K. (1994): Ecotone dynamics and boundary determination in the Great Dismal Swamp. - Ecological Applications 4: 189-203. 
[13] Chang, Y., Bu, R.C., Hu, Y.M., Xu, C.G., Wang, Q.L. (2003): Detecting forest landscape boundary between mountain birch and evergreen coniferous forest in the northern slope of Changbai Mountain. - Journal of Environmental Sciences-China 15: 182-186.

[14] Choesin, D.N. (2001): Use of landscape ecological analysis to determine ecotone locations: an evaluation based on field data. - Jurnal Matematika \& Sains 6: 91-99.

[15] Choesin, D., Boerner, R.E.J. (2002): Vegetation boundary detection: A comparison of two approaches applied to field data. - Plant Ecology 158: 85-96.

[16] Clements, F.E. (1936): Nature and structure of the climax. - Journal of Ecology 24: 252284.

[17] Collins, S.L., Glenn, S.M., Roberts, D.W. (1993): The hierarchical continuum concept. Journal of Vegetation Science 4: 149-156.

[18] Cornelius, J.M., Kemp, P.R., Ludwig, J.A., Cunningham, L. (1991): The distribution of vascular plant species and guilds in space and time along a desert gradient. - Journal of Vegetation Science 2: 59-72.

[19] Cornelius, J.M., Reynolds, J.F. (1991): On determining the statistical significance of discontinuities with ordered ecological data. - Ecology 72: 2057-2070.

[20] Dale, M.R.T., Mah, M. (1998): The use of wavelets for spatial pattern analysis in ecology. - Journal of Vegetation Science 9: 805-814.

[21] Daubenmire, R. (1966): Vegetation: identification of typal communities. - Science 151: 291-298.

[22] di Castri, F., Hansen, A.J. (1992): The environment and development crises as determinants of landscape dynamics. - In: Hansen, A.J., di Castri, F. (eds.) Landscape Boundaries: Consequences for biotic diversity and ecological flows, Springer, New York.

[23] Dupuch, A., Fortin, D. (2013): The extent of edge effects increases during postharvesting forest succession. - Biological Conservation 162: 9-16.

[24] Erdős, L., Bátori, Z., Morschhauser, T., Körmöczi, L. (2013): Ecological boundaries at different scales: testing the moving split window analysis using artificial and field data. Polish Journal of Ecology 61: 319-328.

[25] Erdős, L., Gallé, R., Bátori, Z., Papp, M., Körmöczi, L. (2011): Properties of shrubforest edges: a case study from South Hungary. - Central European Journal of Biology 6: 639658.

[26] Erdős, L., Körmöczi, L., Morschhauser, T. (2008): Növényközösségek határainak kimutathatósága sokváltozós elemzési eljárásokkal. - In: Csima, P., Dublinszki-Boda, B. (eds.) Tájökológiai kutatások, Budapesti Corvinus Egyetem, Budapest.

[27] Erdős, L., Méri, Á., Bátori, Z., Gallé, R., Körmöczi, L. (2012): North-south facing vegetation gradients in the Villány Mts: a case study on the population and the community level. - Pakistan Journal of Botany 44: 927-932.

[28] Erdős, L., Zalatnai, M., Bátori, Z., Körmöczi, L. (2014): Transitions between community complexes: a case study analysing gradients through mountain ridges in South Hungary. - Acta Botanica Croatica 73: 63-77.

[29] Fagan, W.F., Fortin, M-J., Soykan, C. (2003): Integrating edge detection and dynamic modeling in quantitative analyses of ecological boundaries. - BioScience 53:730-738.

[30] Fortin, M-J. (1994): Edge detection algorithms for two-dimensional ecological data. Ecology 75: 956-965.

[31] Fortin, M-J., Dale, M. (2005): Spatial analysis: a guide for ecologists. - Cambridge University Press, Cambridge.

[32] Fortin, M-J., Drapeau, P. (1995): Delineation of ecological boundaries: comparison of approaches and significance tests. - Oikos 72: 323-332.

[33] Fortin, M-J., Drapeau, P., Jacquez, G.M. (1996): Quantification of the spatial cooccurrences of ecological boundaries. - Oikos 77: 51-60.

[34] Fortin, M-J., Olson, R.J., Ferson, S., Iverson, L., Hunsaker, C., Edwards, G., Levine, D., Butera, K., Klemas, V. (2000): Issues related to the detection of boundaries. - Landscape Ecology 15: 453-466. 
[35] Gallé, R., Torma, A., Körmöczi, L. (2007): Epigeic invertebrate assemblages (Araneae, Heteroptera) of natural forest edges - Preliminary results. - In: Tajoský, K., Schlaghamerský, J., Pižl, V. (eds.) Contributions to soil zoology in Central Europe II., Academy of Sciences of the Czech Republic, České Budějovice.

[36] Gillison, A.N., Brewer, K.R.W. (1985): The use of gradient directed transects or gradsects in natural resource surveys. - Journal of Environmental Management 20: 103127.

[37] Gleason, H.A. (1926): The individualistic concept of the plant association. - Bulletin of the Torrey Botanical Club 53: 7-26.

[38] Gosz, J.R. (1993): Ecotone hierarchies. - Ecological Applications 3: 369-376.

[39] Gosz, J.R., Sharpe, P.J.H. (1989): Broad-scale concepts for interactions of climate, topography, and biota at biome transitions. - Landscape Ecology 3: 229-243.

[40] Hansen, A.J., di Castri, F., Naiman, R.J. (1988): Ecotones: What and why? - In: di Castri, F., Hansen, A.J., Holland, M.M. (eds.) A new look at ecotones: emerging international projects on landscape boundaries, International Union of Biological Sciences, Paris.

[41] Harper, K.A., Macdonald, S.E. (2001): Structure and composition of riparian boreal forest: new methods for analyzing edge influence. - Ecology 82: 649-659.

[42] Hennenberg, K.J., Goetze, D., Kouamé, L., Orthmann, B., Porembski, S. (2005): Border and ecotone detection by vegetation composition along forest-savanna transects in Ivory Coast. - Journal of Vegetation Science 16: 301-310.

[43] Hoagland, B.W., Collins, S.L. (1997): Gradient models, gradient analysis, and hierarchical structure in plant communities. - Oikos 78: 23-30.

[44] Hobbs, E.R. (1986): Characterizing the boundary between California annual grassland and coastal sage scrub with differential profiles. - Vegetatio 65: 115-126.

[45] Holland, M.M. (1988): SCOPE/MAB technical consultations on lanscape boundaries. Report of a SCOPE/MAB workshop on ecotones 5-7 January 1987, Paris, France. - In: di Castri, F., Hansen, A.J., Holland, M.M. (eds.) A new look at ecotones: emerging international projects on landscape boundaries, International Union of Biological Sciences, Paris.

[46] Horváth, A. (1998): INFOTHEM program: new possibilities of spatial series analysis based on information theory. - Tiscia 31: 71-84.

[47] Hufkens, K., Scheunders, P., Ceulemans, R. (2009): Ecotones in vegetation ecology: methodologies and definitions revisited. - Ecological Research 24: 977-986.

[48] Ibanez, T., Munzinger, J., Gaucherel, C., Curt, T., Hély, C. (2013): Inferring savannahrainforest boundary dynamics from vegetation structure and composition: a case study in New Caledonia. - Australian Journal of Botany 61: 128-138.

[49] Jacquez, G.M., Maruca, S., Fortin, M-J. (2000): From fields to objects: A review of geographic boundary analysis. - Journal of Geographical Systems 2: 221-241.

[50] Johnston, C.A., Pastor, J., Pinay, G. (1992): Quantitative methods for studying landscape boundaries. - In: Hansen, A.J., di Castri, F. (eds.) Landscape boundaries: Consequences for biotic diversity and ecological flows, Springer, New York.

[51] Kent, M., Gill, W.J., Weaver, R.E., Armitage, R.P. (1997): Landscape and plant community boundaries in biogeography. - Progress in Physical Geography 21: 315-353.

[52] Kirkman, L.K., Drew, M.B., West, L.T., Blooed, E.R. (1998): Ecotone characterization between upland longleaf pine/wiregrass stands and seasonally-ponded isolated wetlands. - Wetlands 18: 346-364.

[53] Körmöczi, L. (2005): On the sensitivity and significance test of vegetation boundary detection. - Community Ecology 6: 75-81.

[54] Körmöczi, L., Jusztin, I. (2003): Homoki gyepközösségek határzónájának szezonális dinamikájáról. - A CSEMETE Egyesület Évkönyve 3: 163-177.

[55] Kröger, R., Khomo, L.M., Levick, S., Rogers, K.H. (2009): Moving window analysis and riparian boundary delineation on the Northern Plains of Kruger National Park, South Africa. - Acta Oecologica 35: 573-580.

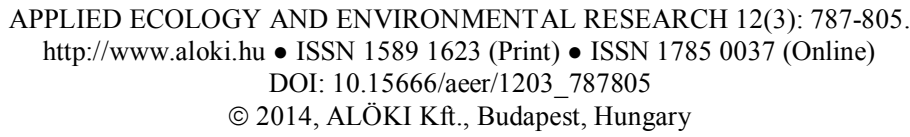


[56] Kröger, R., Rogers, K.H. (2005): Roan (Hippotragus equinus) population decline in Kruger National Park, South Africa: influence of a wetland boundary. - European Journal of Wildlife Research 51: 25-30.

[57] Laliberte, L., Luken, J.O., Hutchens, J.J., Godwin, K.S. (2007): The ecological boundaries of six Carolina bays: community composition and ecotone distribution. Wetlands 27: 873-883.

[58] Laurance, W.F., Didham, R.K., Power, M.E. (2001): Ecological boundaries: a search for synthesis. - Trends in Ecology and Evolution 16: 70-71.

[59] Li, L.G., He, X.Y., Li, X.Z., Wen, Q.C., Zhao, Y.H. (2005): Comparison of two approaches for detecting the depth of edge influence on vegetation diversity in the arid valley of southwestern China. - Journal of Forestry Research 16: 105-108.

[60] Li, L., He, X., Li, X., Wen, Q., He, H.S. (2007): Depth of edge influence of the agricultural-forest landscape boundary, Southwestern China. - Ecological Research 22: 774-783.

[61] Ludwig, J.A., Cornelius, J.M. (1987): Locating discontinuities along ecological gradients. - Ecology 68: 448-450.

[62] Ludwig, J.A., Tongway, D.J. (1995): Spatial organisation of landscapes and its function in semi-arid woodlands, Australia. - Landscape Ecology 10: 51-63.

[63] Magura, T. (2002): Carabids and forest edge: spatial pattern and edge effect. - Forest Ecology and Management 157: 23-37.

[64] Muñoz-Reinoso, J.C. (2001): Sequential pattern in the stabilized dunes of Doñana Biological Reserve (SW Spain). - Journal of Coastal Research 17: 90-94

[65] Muñoz-Reinoso, J.C. (2009): Boundaries and scales in shrublands of the Doñana Biological Reserve, southwest Spain. - Landscape Ecology 24: 509-518.

[66] Muñoz-Reinoso, J.C., García Novo, F. (2000): Vegetation patterns on the stabilized sands of Doñana Biological Reserve. - In: White, P.S.,. Mucina, L., Leps, J. (eds.) Vegetation science in retrospect and perspective, IAVS Opulus Press, Uppsala.

[67] Muñoz-Reinoso, J.C., García Novo, F. (2005): Multiscale control of vegetation patterns: the case of Doñana (SW Spain). - Landscape Ecology 20: 51-61.

[68] Nishimura, T.B., Kohyama, T. (2002): Formation and maintenance of community boundaries in a sub-alpine forest landscape in northern Japan. - Journal of Vegetation Science 13: 555-564.

[69] Nwadialo, B.E., Hole, F.D. (1988): A statistical procedure for partitioning soil transects. - Soil Science 145: 58-62.

[70] Pärn, J., Remm, K., Mander, Ü. (2010): Correspondence of vegetation boundaries to redox barriers in a Northern European moraine plain. - Basic and Applied Ecology 11: $54-64$.

[71] Ricklefs, R.E. (1973): Ecology. - Chiron, Newton.

[72] Ries, L., Fletcher, R.J., Battin, J., Sisk, T.D. (2004): Ecological responses to habitat edges: mechanisms, models, and variability explained. - Annual Review of Ecology, Evolution and Systematics 35: 491-522.

[73] Risser, P.G. (1995): The status of the science examining ecotones. - BioScience 45: 318325.

[74] Rosenberg, M.S., Anderson, C.D. (2011): PASSaGE: Pattern Analysis, Spatial Statistics and Geographic Exegesis. Version 2. - Methods in Ecology and Evolution 2: 229-232.

[75] Ross, M.S., Gaiser, E.E., Meeder, J.F., Lewin, M.T. (2001): Multi-taxon analysis of the "white zone", a common ecotonal feature of South Florida coastal wetlands. - In: Porter, J.W., Porter, K.G. (eds.) The Everglades, Florida Bay, and coral reefs of the Florida Keys: an ecosystem sourcebook, CRC Press, Boca Raton.

[76] Stanisci, A., Lavieri, D., Acosta, A., Blasi, C. (2000): Structure and diversity trends at Fagus timberline in central Italy. - Community Ecology 1: 133-138.

[77] Strayer, D.L., Power, M.E., Fagan, W.F., Pickett, S.T.A., Belnap, J. (2003): A classification of ecological boundaries. - BioScience 53: 723-729. 
[78] Tolman, D.A. (2006): Characterization of the ecotone between Jeffrey pine savannas and Darlingtonia fens in Southwestern Oregon. - Madroño 53: 199-210.

[79] Torma, A., Körmöczi, L. (2009): The influence of habitat heterogeneity on the fine-scale pattern of an Heteroptera assemblage in a sand grassland. - Community Ecology 10: 7580 .

[80] van der Maarel, E. (1974): Small-scale vegetational boundaries: on their analysis and typology. - In: Sommer, W.H., Tüxen, R. (eds.) Tatsachen und Probleme der Grenzen in der Vegetation, Cramer Verlag, Lehre.

[81] van der Maarel, E. (1976): On the establishment of plant community boundaries. Berichte der Deutschen Botanischen Gesellschaft 89: 415-443.

[82] Watkins, R.Z., Chen, J., Pickens, J., Brosofske, K.D. (2003): Effects of forest roads on understory plants in a managed hardwood landscape. - Conservation Biology 17: 411419.

[83] Webster, R. (1973): Automatic soil-boundary location from transect data. - Journal of the International Association for Mathematical Geology 5: 27-37.

[84] Webster, R. (1978): Optimally partitioning soil transects. - Journal of Soil Science 29: 388-402.

[85] Webster, R., Wong, I.F.T. (1969): A numerical procedure for testing soil boundaries interpreted from air photographs. - Photogrammetria 24: 59-72.

[86] Werger, M.J.A., Louppen, J.M.W., Eppink, J.H.M. (1983): Species performances and vegetation boundaries along an environmental gradient. - Vegetatio 52: 141-150.

[87] Whittaker, R.H. (1960): Vegetation of the Siskiyou Mountains, Oregon and California. Ecological Monographs 30: 279-338.

[88] Whittaker, R.H. (1967): Gradient analysis of vegetation. - Biological Reviews 42: 207264.

[89] Wierenga, P.J., Hendrickx, J.M.H., Nash, M.H., Ludwig, J., Daugherty, L.A. (1987): Variation of soil and vegetation with ditance along a transect in the Chihuahuan Desert. Journal of Arid Environments 13: 53-63.

[90] Wilson, J.B. (2004): Ecology or mythology? Are Whittaker's "gradient analysis" curves reliable evidence of continuity in vegetation? - Preslia 76: 245-253.

[91] Wilson, J.B. (2009): The Clements-Gleason concept of the plant community. - In: Coles, S., Dimopoulos, P. (eds.) Abstracts of the 52nd IAVS international symposium, IAVS, Chania.

[92] Xu, D., Xu, X., Xie, Y., Wang, K. (2012): Dynamics of sandy desertification and detection of sandy land/steppe boundary: vegetation and soil properties. - Polish Journal of Ecology 60: 251-263.

[93] Yarrow, M.M., Marín, V.H. (2007): Toward conceptual cohesiveness: a historical analysis of the theory and utility of ecological boundaries and transition zones. Ecosystems 10: 462-476.

[94] Zalatnai, M., Körmöczi, L. (2004): Fine-scale pattern of the boundary zones in alkaline grassland communities. - Community Ecology 5: 235-246.

[95] Zalatnai, M., Körmöczi, L., Tóth, T. (2007): Community boundaries and edaphic factors in saline-sodic grassland communities along an elevation gradient. - Tiscia 36: 7-15.

[96] Zalatnai, M., Körmöczi, L., Tóth, T. (2008): Soil-plant interrelations and vegetation boundaries along an elevation gradient in a Hungarian sodic grassland. - Cereal Research Communications 36: 231-234. 